\title{
Exploring Visual Arts Students in Chinese High School
}

\author{
Zhaoqian Yue ${ }^{1, *}$ \\ ${ }^{I}$ International College for Chinese Studie, Nanjing Normal University, Nanjing, 210024,Jiangsu, China \\ "Corresponding author. Email: 24190131@njnu.edu.cn
}

\begin{abstract}
In China, despite the strong promotion in aesthetic education, to our knowledge, the subject of visual arts is still be neglected by the public. The population of visual arts students, especially those who choose it as their major in high school, is experiencing the burden of people's innumerable prejudices and preconceptions. However, there are very few studies in English that explore the barriers suffered by visual arts students. This paper aims at helping the public raise the awareness of visual arts and visual arts students. After introducing China's system of Beaux-arts college entrance examination and an overview of the new policy reform in 2021, this paper summarizes some typical barriers faced by visual arts students from three dimensions. According to the literature review, the results indicate that the social, economic and mental obstacles experienced by visual arts students have a formative and fundamental impact on their future pursuit of visual arts and even their career and life development. This paper also puts forward some constructive suggestions with the purpose of promoting the progress of visual arts reform and helping visual arts students get more understandings and supports. The whole study suggests that much attention should be paid to the subject of visual arts and visual arts students. In the meantime, corresponding reforms and policy implementation also need to be accelerated.
\end{abstract}

Keywords: Beaux-arts College Entrance Examination, High School Visual Arts Education, Phenomena, Barriers, Aesthetic Education, Constructive Suggestions, Social reproduction.

\section{INTRODUCTION}

According to the Press Conference of the Ministry of Education of the People's Republic of China (MOE of PRC), almost 1,170,000 arts students sat the College Entrance Examination (Gaokao), accounting for almost $11 \%$ of all Gaokao students [1]. Though the number of art students has declined remarkably in 2021, owing to the uncertain epidemic and the reform of the college entrance examination, a large portion of students still chooses art as their major in high school. In this group, more than $80 \%$ of them are visual arts students [2]. However, few scholars have paid attention to this huge population. In addition, many people still hold considerable biases against visual arts and visual arts students, meaning that the field of visual arts has not been fully understood and recognized. Therefore, this paper focuses on visual arts students in Chinese high school, aiming to make people have an in-depth understanding of visual arts education.

This paper addresses the question: how do social, economic, and mental barriers affect students' pursuit of visual arts education in Chinese high school? Through starting by offering a snapshot of the Beaux-arts college entrance examination system in China, and the current reform in 2021, the first impression of visual arts will be got. In the second part of the paper, much emphasis is put on analyzing social, economic, and mental barriers against visual arts students. In the last section, several constructive methods are put forward to make the internal and external environment of visual arts education in China more harmonious.

\section{BEAUX-ARTS COLLEGE ENTRANCE EXAMINATION FOR CHINESE HIGH SCHOOL STUDENTS IN CONTEXT}

The Beaux-arts college entrance examination is not only an effective means in selecting talents for the college but also the fundamental instructions for the basic visual arts education, especially in high school, which has a profound impact on the effect of the implementation on art majors in college, and even the whole country's visual arts education. Meanwhile, it also exerts a subtle influence on the public's quality of aesthetic and spiritual development [3]. Hence, having a 
comprehensive understanding of the Chinese Beaux-arts college entrance examination system indeed counts.

Since 2006, the MOE of PRC has published detailed requirements for the subjects of the Beaux-arts college entrance examination, which standardizes the field of visual arts. Relevant regulations were put forward in 2008 emphasized that the Buaex-arts college entrance examination has two categories: one is organized by every province; the other is held by some colleges which have the special and concrete demand for students [4]. For every visual arts student, sitting the examination held by the province is a must. Some ordinary colleges only require this examination performance as their final application requirement. However, if visual arts students want to pursue better colleges (e.g., Central Academy of Fine Arts, Tsinghua University), they should sit examinations organized by corresponding colleges. Some students even took more than twenty examinations to increase their success rate [5]. These two forms of visual arts examination have operated smoothly in recent years.

Though the system of visual arts examination changed almost every year, the overall outline of the system has not be transformed until 2021. The MOE of PRC proposed further strengthening and improving the examination and enrollment of art majors in ordinary colleges. As the document points out, the scope and scale of the visual arts examination organized by some colleges will be strictly controlled, the categories of the visual arts examination held by every province will be actively enlarged, and the requirements for academic performance will be gradually strengthened [6]. This reform means that the system of Beaux-arts college entrance examination will be more and more scientific and fair.

\section{BARRIERS FACED BY VISUAL ARTS STUDENTS IN CHINESE HIGH SCHOOL}

With the development of society, the rise of cultural industries, the expansion of the art market, and the strengthening of social demand for visual arts, the social demand for visual arts talents is also expanding [3]. An increasing number of students choose visual arts as their major in high school for a variety of reasons. However, the constant progress of the time does not mean that the public can fully be open to different kinds of ideas. A large portion of visual arts students still suffers barriers from different dimensions in their daily life.

\subsection{Social Barriers}

Many social barriers are faced by students who choose visual arts as their major in Chinese high school. This paper points out three typical social barriers.
Firstly, due to the outbreak of COVID-19 in 2020, the college entrance examination for visual arts students is full of uncertainty. Zhao refers that the sudden outbreak of the epidemic has made the traditional Beaux-arts college entrance examination model no longer feasible. The traditional system of Beaux-arts college entrance examination is relatively low in efficiency and costs a lot of resources [7].

For one thing, the examination is constantly in danger of being delayed, which not only has an adverse impact on the process of talents selection but also physically and mentally challenges relevant visual arts students. Therefore, turning to online tests is being more and more colleges' choices. For example, in 2020, many colleges conducted online preliminary tests and interviews as their means of talent selection.

For another, adopting online ways of selection has both strengthens and weaknesses. It is pretty convenient for students and colleges, but various drawbacks occur. First and foremost, the Internet connection always troubles us, especially in remote rural areas. In addition, it is essential to consider how to effectively prevent the cheating phenomena. College entrance examination results play an important role in determining transitions to tertiary education, and in determining the type of education received [8]. The Beaux-arts college entrance examination also plays the above roles. Therefore, it is vital to ensure that online talent selection is equal and fair. According to Zhao, many corresponding technical and rule-making difficulties have been overcome. For example, the network examination platform and the standardized test space requirements have been established [7]. But for the training of examiners and the emergency disposal plan, further exploration is still a necessity. Under the huge pressures of the epidemic prevention and control, relevant colleges should endeavor to think and create innovative, effective, and equanl arts examination models [9].

Secondly, the current policy of the Beaux-arts college entrance examination is far from satisfactory. Hence, corresponding reform is a must for the government and school. In 2020, many colleges (e.g., nine famous visual arts colleges in China) changed their ways of visual arts examination. As one of the governors said, the selection of provincial unified examination as the primary selection for visual arts examination is one of the directions of national policy adjustment for Beaux-arts College Entrance Examination, and the epidemic has accelerated the speed of such reforms [10]. However, adaptation to the new reform is always not an easy thing, which not only requires much effort to transform the ideology into specific actions but also needs a large amount of time to completely change the current systems and individuals' original perceptions. 
Thirdly, influenced by the poor economic and cultural development and backward conception in remote regions, especially in remote ethnic regions, the visual arts education in high school lags far behind developed regions, including the unbalanced distribution of teaching resources, school facilities, and effective support policies. Such limited social resources are detrimental to students in rural areas to pursue their visual arts dreams. If the problem of unequal resources distribution is not be effectively alleviated, the reproduction of educational inequalities will expand to all aspects of our society and be much worse.

Furthermore, the society which can be regarded as the foundation has a very close connection with the dimensions of economy and individual psychology. Only when social obstacles faced by visual arts students are better off dealing with can challenges of other dimensions be paid much more attention.

\subsection{Economic Barriers}

Visual arts students will spend much more money than other students who choose to attend the general Gaokao. Guo refers that it costs at least 20,000 yuan (tuition and fees are excluded) per student for three years in a Chinese high school in 2012, including various drawing materials' fees, extra-training fees, and Beaux-arts college entrance examination fees [11]. Nine years later, the cost is only going to be even more unaffordable. For impoverished families, it is extremely difficult to support their children to learn visual arts. In other words, visual arts now seems to be a luxury that only families of the middle or high class can afford.

Though many poverty alleviation policies have been implemented, visual arts students seem no longer to have to worry about not being able to pay tuition and fees. As a matter of fact, to have more opportunities to be admitted to good colleges, extra-training where students can gain more specific and targeted training is now almost being a necessity for every visual arts student. A student graduating from a Chinese high school featuring visual arts said, she spent about 50,000 yuan on just a pre-exam training in other countries of China. The fees for extra-training are exorbitant. A bad phenomenon subsequently arises, in which the more money the student pay, the more chances the student will get. With time passing, impoverished visual arts students will be less and less likely to go to colleges but vocational schools. To a large degree, the elites are more likely to remain their classes as elites. The interplays between education reproduction and social reproduction mutually intensify, which makes the society much more unequal.

\subsection{Mental Barriers}

Visual arts students experience a large number of biases and discrimination in their daily life from different levels: society, family, and gender.

On the society level, people generally perceive visual arts as a profession with no effort. On the one hand, this stereotype is caused by the current phenomenon where a significant number of students choose visual arts as a major just for taking the shortcut not because of their interests or dreams. The main reasons are that its requirement of academic performance is not high, and it seems to take effect merely through a few-month intensive course. On the other hand, a large portion of people still hold the view that painting just requires talent and the talented can easily get access to colleges without too much practice and preparation. This bias means that visual arts students' diligence and achievement are hardly recognized by the public. Additionally, visual arts students are always considered as the population of good economic conditions, because visual arts requires a big upfront investment. In fact, the interviewees pointed out that most visual arts students do not have superior economic conditions, and most of them are just from the middle class. Such stereotypes have an adverse impact on visual arts students with bad economic conditions, which makes impoverished students who truly want to pursue visual arts gradually lose their confidence and faith.

On the family level, several parents think visual arts have a bleak, gloomy prospect, specifically, with unsteady jobs and lower social status compared to other occupations. Many students who have enthusiasm for visual arts give up their goals or dreams only for living up to their parents' expectations. Even if they succeed in choosing visual arts as their major in high school, no support from their parents also badly influences their school performance and future path. Both and teachers promote a close family-school relationship [12]. Family of a close relationship with school can yield a lot of profit. For students whose parents do not support them to choose visual arts as their major, it is hard for them to achieve good school performance and have more chances in future tertiary education. In the long run, school processes contribute to social reproduction [13].

On the gender level, compared to women, men are given more understanding and support to explore and develop visual arts which are considered as an unpromising and costly major by the public. While most girls are expected to choose more practical majors rather than visual arts based on biased gender expectation. Study shows that biased gender expectation affects both major and career choices: people's acceptance of the gender system justifies men's gender power and privilege in society [14]. Men are considered highly legitimate, and the public tends to hold the belief that their boys are more likely to gain achievements in the field of visual arts. The biased gender expectation can 
exacerbate gender inequality, providing female students fewer opportunities to pursue their goals of visual arts.

\section{CONSTRUCTIVE SUGGESTIONS}

For students learning visual arts, they might rise to different dimensions of challenges. To make the internal and external environment of visual arts more harmonious and equal, several constructive suggestions will be put forward.

\subsection{Continue to Strengthen the Promotion of Aesthetic Education}

Aesthetic education is not only to cultivate excellent artistic talents but also an important educational practice that is necessary for every student. In 2020, the government proposed that aesthetic education should be incorporated into the whole process of students' cultivation in schooling, aiming at fostering socialist builders and successors who are well-developed morally, intellectually, physically, aesthetically, and artistically [15]. For example, aesthetic education will be evaluated in the high school entrance examination. The 2021 National People's Congress and the Chinese People's Political Consultative Conference (NPC \& CPPCC), more constructive suggestions were made to facilitate the progress of aesthetic education. Therefore, what we should do is to persist in improving aesthetic education, which can both enhance students' overall quality and effectively eliminate the public's discrimination against visual arts students.

\subsection{Deepening the Reform of Visual Arts Course in High School Comprehensively}

Nowadays, a large portion of visual arts students is overly dependent on expensive extra-training institutions. Some institutions even have a monopoly. The main reason is that school courses do not have close contact with the Beaux-arts college entrance examination [16]. Consequently, the high school course system should be firmly reformed. In terms of the school course, more attention to visual arts students' learning plans should be paid in high school teaching strategies. Meanwhile, teachers should not only put emphasis on imparting the knowledge and skills about visual arts but also promote the cultivation of students' overall quality. In addition, academic performance is of great importance as well as visual arts performance. The school should focus on both students' art performances and academic cultivations. Only when the school course is comprehensively reformed can visual arts students from different classes truly embrace the bright future with equal chances to develop.

\subsection{Cultivating a Harmonious Family Atmosphere}

A favorable family atmosphere is conducive to a student's career and life development. As one kind of cultural capital, the relationship between children and parents is very important, which not only has a great influence on students' school performance but also crucial to the formation of their value systems. Both parents and students should realize that visual arts are definitely not the shortcut for college or the less valued education. For parents, learning to understand and support is important. For children who choose the path of visual arts, respect, and hard work matter. Only when such a harmonious family atmosphere is built can students truly gain knowledge and happiness from visual arts.

\section{CONCLUSION}

This paper has presented an overview of the field of visual arts and visual arts students in China by offering a snapshot of the examination system and revealing the existing barriers faced by visual arts students. Despite visual art students being faced with many social, economic, and mental obstacles, considerable methods have been implemented and several constructive suggestions are put forward to alleviate these problems. The exploration of visual arts students in Chinese high school enables the public to have a well-rounded understanding of visual arts and give more recognition and support to this prejudiced population. To make this group widely accepted, improving aesthetic education in the whole society is the most important. In addition, relevant reforms also need to be accelerated with the purpose to make every student who truly loves visual arts freely and happily pursue their dreams and goals. Though many methods nowadays are still far from perfect, we should be positive for a serious commitment to combating inequality and the stereotypes existing in the field of visual arts.

\section{REFERENCES}

[1] Ministry of Education of the People's Republic of China. (2020, May 12). Press Conference. http://www.moe.gov.cn/fbh/live/2020/51974/

[2] Ministry of Education of the People's Republic of China. (2016, October 8). Reply of No. 5254 recommendation of the fourth session of the twelfth National People's Congress. http://www.moe.gov.cn/jyb_xxgk/xxgk_jyta/jyta_x ueshengsi/201611/t20161107_287933.html

[3] Huang, C. (2008). Analysis and suggestion of Beaux-arts College Entrance Examination phenomena. [Master dissertation, Nanjing University of the Arts]. Master. (in Chinese) 
https://kns.cnki.net/KCMS/detail/detail.aspx?dbna $\mathrm{me}=\mathrm{CMFD} 2009 \&$ filename $=2008184637 . \mathrm{nh}$

[4] Ministry of Education of the People's Republic of China. (2007, September 16). Notice on the recruitment of art majors in 2008. http://www.moe.gov.cn/srcsite/A15/moe_776/s310 9/200711/t20071116_79730.html

[5] Jiang, J. (2008). A study on system of current college entrance test for art majors in China: Take fine art as an example. [Master dissertation, Nanjing University of the Arts]. Master. (in Chinese)

https://kns.cnki.net/KCMS/detail/detail.aspx?dbna $\mathrm{me}=\mathrm{CMFD} 2009 \&$ filename $=2008184776 . \mathrm{nh}$

[6] Ministry of Education of the People's Republic of China. (2021, September 24). Document on further strengthening and improving the examination and enrollment of arts majors in ordinary colleges and universities.

http://www.moe.gov.cn/jyb_xwfb/gzdt_gzdt/s5987 /202109/t20210924_566333.html

[7] Zhao, J. (2021). Exploration and practice research on examination administration in colleges and universities under the New Policy of Art Examination: Taking art colleges as an example. Academy, (14), 65-67. (in Chinese) doi:CNKI:SUN:XYJK.0.2021-14-021

[8] Hannum, E., An, X., \& Cherng, H. Y. S. (2011). Examinations and educational opportunity in China: Mobility and bottlenecks for the rural poor. Oxford Review of Education, 37(2), 267-305.

[9] Li, X. (2021). Exploration on reform countermeasure of examination administration of art college. Policy Research \& Exploration, (01), 94-95. doi:10.16324/j.cnki.jcts.2021.01.054

[10] Shi, X. (2020). 2020 “Art Examination reform", temporary response or trend?. China Culture Daily, 001 .

[11] Guo, G. (2012). The children of poor families enrolled in art colleges predicament research: Taking Guangxi area as an example. [Master dissertation, Guangxi Normal University]. Master. (in

Chinese) https://kns.cnki.net/kcms/detail/detail.aspx?FileNa $\mathrm{me}=1012377759$. nh $\&$ DbName $=$ CMFD2012

[12] Lareau, A. (1987). Social class differences in family-School relationships: The importance of cultural capital. Sociology of Education, (2). https://doi.org/10.2307/2112583

[13] Aggleton, P. J., \& Geoff, W. (1985). Rebels without a cause? Socialization and subcultural style among the children of the new middle classes. Sociology of Education, 60-72.

[14] Ridgeway, C. L., \& Smith-Lovin, L. (1999). The gender system and interaction. Annual Review Of Sociology, 25(1), 191-216.

[15] General Office of the CPC Central Committee., \& General Office of the State Council. (2020, October 15). Opinions on strengthening and improving school aesthetic education in the new era. http://www.gov.cn/zhengce/202010/15/content_5551609.htm

[16] Zhou, Y., \& Lan, D. (2020). An analysis of the present situation of art examination in China. The Art Literature, (09), 89-90. (in Chinese) doi:10.16585/j.cnki.mswx.2020.09.039 